\title{
The Effect of an Intramammary Teat Seal on New Intramammary Infections
}

\author{
E. A. Berry and J. E. Hillerton \\ Institute for Animal Health, \\ Compton, \\ Berkshire RG20 7NN, \\ United Kingdom
}

\begin{abstract}
As concern over the possible overuse of antibacterials increases, attention has focused on reduction of antibiotic usage and on nonantibiotic alternatives. A nonantibiotic intramammary teat sealant, Teat Seal (Cross Vetpharm Group Ltd., Tallaght, Dublin, Ireland), has been available in Ireland, in combination with an intramammary tube of cloxacillin. Teat Seal has been reformulated for use in cows with low cell counts as an alternative to antibiotic dry cow therapy at the end of lactation. The product is now marketed as Orbeseal (Pfizer Animal Health). A comparison between this teat sealant and no treatment was made on new intramammary infections and clinical mastitis, on all cows within four herds, and on low cell count cows in three herds.

No cases of clinical mastitis in the dry period were observed in cows treated with Teat Seal $(\mathrm{n}=197)$, whereas a significant number (6 cows) were observed in the untreated cows $(n=204)$. In all herds, significantly more new infections at calving were found in the untreated group (62 cows in the untreated group compared with 21 cows in the Teat Seal group). In those quarters where infections were first detected at calving, the incidence of clinical mastitis was significantly greater in the untreated group. Quarters in both treatment groups that were infected at drying off with Corynebacterium spp. or coagulase-negative staphylococci were not protected against new infections and had an increased risk of new infection by Streptococcus uberis. The results will inform those restricting their use of antibiotic dry cow therapy in alternative management strategies and the additional risk of new intramammary infection.
\end{abstract}

(Key Words: Orbeseal, Teat Seal, intramammary infection, mastitis)

Received January 18, 2002.

Accepted April 24, 2002.

Corresponding Author: Elizabeth A. Berry; e-mail: elizabeth. berry@bbsrc.ac.uk.
Abbreviation key: $\mathbf{C N S}$ = coagulase-negative staphylococci.

\section{INTRODUCTION}

In the UK, dry cow therapy is the recommended practice for all cows all year round at the end of lactation. Increasing concerns over the widespread use of antibiotics, along with the observation that many cows are now uninfected at drying off, suggests that a reevaluation of the use of total dry cow therapy is required. Previous work has shown that dry cow therapy still has a significant value in preventing new infections during the dry period and at calving (Berry and Hillerton, 2002; Hassan et al., 1999). There is also an increasing interest in organic dairy production; it is a growing niche market that specifies that antibiotics not be used as prophylactics. Organic milk production commands a price premium and is economically attractive. There is a requirement in all herds for a product to prevent new infections during the dry period. Furthermore, the economics of European dairy farming, with its low price for milk and high costs, requires a regular appraisal of all costs, including total dry cow therapy.

Various types of external teat seals have been available for some time to limit exposure of the teats to bacterial invasion. They have had only limited success in reducing intramammary infections during the dry period, largely due to poor persistence on the teat (Hemling et al., 2000; Timms et al., 1997).

An inert internal teat sealant made from bismuth subnitrate (an inert salt) in a paraffin base (Osmonds Teat Seal, Cross Vetpharm Group, Tallaght, Dublin, Ireland) has been available in Ireland since 1978 sold as a two-syringe intramammary combination with an aqueous form of cloxacillin (Meaney, 1977). A reformulation has also been available in New Zealand without the cloxacillin intramammary since 1997. It is reported to be more effective, especially in maintaining a plug at the teat sinus (Woolford et al., 1998). The Teat Seal (now marketed as Orbeseal [Pfizer Animal Health]) is administered at drying off and forms a physical barrier 
within the teat canal and lower teat sinus. It has been reported that teats classified as "open," without a keratin plug, or that run milk during the dry period are more susceptible to infections during the dry period (Day, 1990; Schukken et al., 1993). Teat Seal may act as an artificial plug comparable to the keratin plug noted in "closed" teats (Comalli et al., 1984; Day, 1990).

Teat Seal has been used in combination with an antibiotic (Woolford et al., 1998), the bacteriocin lactocin 3147 (Ryan et al., 1999), as well as alone. It has successfully prevented new infections during the dry period both from experimental challenge (Meaney, 1977) and from natural exposure in the field, although only in cows with low cell count (Woolford et al., 1998). This product may be a nonantibiotic alternative to total dry cow therapy.

The use of Teat Seal in uninfected cows with low cell counts in seven herds and in all cows in four of these seven herds has been determined. Teat Seal was compared with a negative control for its effects over a full year on the rate of new intramammary infections and on clinical mastitis postpartum.

\section{METHODS}

\section{Trial Design}

Seven dairy herds were recruited for a selective teat sealant trial. There were two herds at the Institute for Animal Health (IAH), two fully commercial organic herds, and three fully commercial herds undergoing conversion to organic status. Monthly geometric bulk milk cell counts ranged from 115,000 to 350,000 cells per ml, but all herds left individual cows' milk out of the bulk tank in order to manipulate bulk milk cell counts to achieve cell count payment standards. Herd yields averaged from 5400 to 7500 liters. Cows were selected from all seven herds on the following criteria: cell count below 200,000 cells per $\mathrm{ml}$ for all routine monthly samples (except for one herd which was on bimonthly monitoring), no clinical intramammary infections during that lactation, and no antibiotic treatments of any type in the $30 \mathrm{~d}$ preceding drying off. Using a random number allocation table, cows were randomly assigned within each herd to one of two groups: Teat Seal and untreated. The remaining cows, from the two IAH herds and the two fully organic herds, not satisfying the selection criteria were also randomly allocated to one of the treatment groups in the same manner. All cows were abruptly dried off at the end of the designated milking. Teat Seal was administered with a standard aseptic technique used for infusing a dry cow antibiotic tube. At the end of milking, the teats were cleaned using cotton wool pledgelets in $70 \%$ ethanol solution until the pledgelets were no longer visibly dirty, and then the Teat Seal was infused using a partial insertion technique. Any cow that required medical or surgical intervention within $14 \mathrm{~d}$ after calving was excluded from the trial. From November 1999 to December 2000, 401 cows were recruited. All cows had a winter housing period on straw bedding and a summer grazing period on grass. All cows were monitored for at least $100 \mathrm{~d}$ after calving and were under natural exposure to infection. Untreated and treated cows were managed as one husbandry group on each farm. Sampling and bacteriological examination of the milk was carried out as per IDF recommendations (IDF, 1981) with extra testing (Berry and Hillerton, 2002). The sampling routine consisted of single samples taken one week prior to drying off, at drying off, at calving, and approximately 1 wk after calving with confirmatory samples as necessary.

\section{Definitions}

When the same pathogen was isolated in two consecutive samples, two out of three samples, or a pathogen came from one milk sample with the cell count elevated in comparison to the other quarter cell counts, this was defined as an infection (IDF, 1981). An elevated cell count was defined as two times greater than that of the other quarters and greater than 200,000 cells per ml.

Clinical mastitis occurred when visible changes in the milk such as watery milk, clots or flakes, or changes in the udder such as swelling or heat were seen. These were either detected by the farm staff or discovered at one of the routine sampling times.

\section{Statistical Analyses}

The data were analyzed using the Minitab statistical computer package (release 12.21, Minitab Inc., Pennsylvania, PA 16801, USA) and SAS system (Version 8, SAS Institute, Cary, NC, USA). Logistic regression, Fisher's exact and $\chi^{2}$ tests were carried out to determine if treatment affected the probability of infection. The effects on the probability of a new infection of treatment, herd, parity, cell count grouping at drying off, and infection status at drying off were determined by logistic regression. To be classified as infected at drying off a cow had to: 1) have at least two quarters infected with Corynebacterium spp. or coagulase-negative staphylococci (CNS) at drying off, or 2) have only one quarter infected at drying off if a new infection had been acquired during the dry period.

Herd was a forced covariate due to herd differences in management, and because some herds only contributed low cell count cows to the data. The two IAH herds were managed as one herd during the dry period, hence data 
Table 1. Number of cows by infection status at calving, cell count group, infection status at drying off, parity, and herd.

\begin{tabular}{lrc}
\hline Group & Teat Seal & Untreated \\
\hline Infection status at calving ${ }^{1}$ & & \\
Infected & 21 & 62 \\
Uninfected & 176 & 139 \\
Cell count grouping & 109 & \\
Low cell count & 88 & 107 \\
$\quad$ Higher cell count & & 94 \\
Infection status at DO & 133 & 120 \\
Uninfected & 53 & 64 \\
Infected with Corynebacterium & 11 & 17 \\
Infected with CNS ${ }^{2}$ & & \\
Parity & 75 & 69 \\
2 & 48 & 51 \\
3 & 74 & 81 \\
4 and above & & \\
Herd & 84 & 83 \\
Herd 1 & 64 & 71 \\
Herd 2 & 13 & 12 \\
Herd 3 & 14 & 14 \\
Herd 4 & 9 & 10 \\
Herd 5 & 13 & 11 \\
Herd 6 & & \\
\hline
\end{tabular}

${ }^{1}$ Odds ratio $([$ Infected $\mid$ Teat Seal $] /[$ Infected $\mid$ Untreated $])=0.27$ Confidence interval $=0.16$ to $0.67, \chi^{2}=24.561 P<0.001$.

${ }^{2} \mathrm{CNS}=$ Coagulase-negative staphylococci.

from these herds were presented as one herd. Parity was defined as those of parity two, three, or four and greater for the lactation after the dry period.

\section{RESULTS}

There were no significant differences in distribution between the two treatment groups for infection status at drying off, cell count groups, parity, or herd. There was a significant difference in the infection status at calving between the treatment groups $(P=0.001)$ (Table 1). Cows treated with Teat Seal were 0.27 times less likely to have a new infection at calving than untreated cows. Binary logistic regression was used to model the relationship between the effects of Teat Seal usage, herd, parity, cell count group, and infection status at drying off on the infection status at calving. All analyses were conducted at the cow level (Table 2). Although herd was not a significant confounder, it remained in the model as forced covariate. The analysis was performed by using forward and backward stepwise regression.

Teat seal was the most significant covariate. Infection status at drying off and cell count group were significant covariates, but parity was not a significant covariate. There were no significant interactions. Goodness-of-fit tests using the log likelihood ratio demonstrated that the final model included treatment, cell count group, infection status at drying off, and herd, but not parity (Table 2). Logistic regression at the quarter level demonstrated the same significant covariates (results not shown).

There were no significant differences in the total number of quarters infected with Corynebacterium spp. between Teat Seal and untreated cows at drying off within cell count groups $(P=0.5)$. A difference in the percentage of quarters infected with Corynebacterium spp. between herds at drying off was demonstrated using a $\chi^{2}$ test $(P<0.001)$ (Table 3$)$. There was a significantly higher number of infections due to Staphylococcus aureus in the high cell count group than the lower cell count group ( $\left.\chi^{2}=12.611, P=<0.001\right)$ at drying off, but again there were herd variations, with some herds having no cows infected with $S$. aureus at drying off. The presence of a $S$. aureus infection at drying off did not significantly increase the risk of a new infection at calving. Only one cow with a quarter infected with $S$.

Table 2. Final binary logistic regression model of probability of infection at calving. Results of final model with covariates:treatment, cell count groups, infection status at drying off, and herd.

\begin{tabular}{|c|c|c|c|c|c|}
\hline Variable & Coefficient & $\begin{array}{l}\text { Standard } \\
\text { Error }\end{array}$ & $\begin{array}{l}\text { Odds } \\
\text { Ratio }\end{array}$ & $\begin{array}{l}95 \% \text { confidence } \\
\text { interval of odds } \\
\text { ratios }\end{array}$ & $P$ value \\
\hline Constant & -2.9237 & 0.4058 & & & Oxoroll \\
\hline Herd & & & & & 0.616 \\
\hline $\begin{array}{l}\text { Exposure variable-treatment } \\
\text { Teat Seal }\end{array}$ & 0 & & & & \\
\hline Untreated & 1.3017 & 0.2926 & 3.68 & $2.07-6.52$ & $<0.001$ \\
\hline $\begin{array}{l}\text { Cell count group } \\
\text { Low }\end{array}$ & 0 & & & & \\
\hline Higher & 0.6894 & 0.3065 & 1.99 & $1.08-3.66$ & $\begin{array}{c}0.026 \\
\text { Overall }\end{array}$ \\
\hline $\begin{array}{l}\text { Drying off status } \\
\text { Other }\end{array}$ & 0 & & & & $<0.001$ \\
\hline Corynebacterium spp. & 1.4698 & 0.3065 & 4.35 & $2.38-7.93$ & $<0.001$ \\
\hline $\mathrm{CNS}^{1}$ & 1.0172 & 0.4871 & 2.77 & $1.06-7.18$ & 0.037 \\
\hline
\end{tabular}

${ }^{1} \mathrm{CNS}=$ Coagulase-negative staphylococci. 
Table 3. Percentage of Corynebacterium spp. infections in quarters at drying off by herd and cell count group.

\begin{tabular}{|c|c|c|c|c|c|}
\hline & \multicolumn{5}{|c|}{ Percentage of Corynebacterium spp. at the Quarter Level } \\
\hline & \multirow[b]{2}{*}{ Total percentage $\mathrm{a}^{\mathrm{a}}$} & \multicolumn{2}{|c|}{$\begin{array}{l}\text { Percentage in cows with } \\
\text { low cell counts }\end{array}$} & \multicolumn{2}{|c|}{$\begin{array}{l}\text { Percentage in cows with } \\
\text { high cell counts }\end{array}$} \\
\hline & & Teat Seal & Untreated & Teat Seal & Untreated \\
\hline Herd 1 & 24 & 20 & 15 & 26 & 29 \\
\hline Herd 2 & 26 & 25 & 18 & 26 & 33 \\
\hline Herd 3 & 55.5 & 40 & 51 & 73 & 81 \\
\hline Herd 4 & 76.6 & 71 & 78 & - & - \\
\hline Herd 5 & 0 & 0 & 0 & - & - \\
\hline Herd 6 & 66.6 & 64 & 70 & - & - \\
\hline Total & 32 & 34 & 32 & 28 & 35 \\
\hline
\end{tabular}

${ }^{\mathrm{a}}$ numbers differ between rows $\chi^{2}=47.4, P<0.001$.

aureus at drying off acquired a new $S$. aureus infection in another quarter.

The following results for infection status are limited to streptococci, coliforms, S. aureus, and Arcanobacterium pyogenes. Infections due to CNS and Corynebacterium spp. are not included in the analysis unless otherwise stated.

\section{Cows and Quarters Infected During the Dry Period}

There was a statistically significant difference in the incidence of clinical mastitis during the dry period (Table 4); clinical signs of mastitis were detected in six cows (10 quarters), all from the untreated group ( $P=$ 0.0167 for cow and $P=0.001$ for quarter), and none from the Teat Seal group. Two cows were treated with short-acting lactating cow intramammary formulations in the affected quarters. Data from these cows are included in the infection status at calving column. One quarter in one cow involuted at calving, and the other three infected cows were treated with a long-acting intramammary dry cow formulation in all quarters; these are not shown in the column for infection status at calving. The predominant infection isolated from clinical infections during the dry period was Streptococcus uberis. One cow from the Teat Seal group was accidentally treated after a misdiagnosis of clinical mastitis in the dry period and was removed from the trial.

Table 4. Numbers of cows and quarters detected with clinical mastitis during the dry period in all herds.

\begin{tabular}{lllllllr}
\hline & \multicolumn{3}{c}{ Cow $^{\mathrm{a}}$} & & \multicolumn{3}{c}{ Quarter $^{\mathrm{b}}$} \\
\cline { 2 - 4 } \cline { 6 - 7 } \cline { 6 - 7 } & No & Yes & Total & & No & Yes & Total \\
\hline Teat Seal & 197 & 0 & 197 & & 784 & 0 & 784 \\
Untreated & 198 & 6 & 204 & & 802 & 10 & 812 \\
Total & 395 & 6 & 401 & & 1586 & 10 & 1596 \\
\hline
\end{tabular}

${ }^{\mathrm{a}} P=0.0167$, Test of association Fisher's exact.

${ }^{\mathrm{b}} P=0.0011$, Test of association Fisher's exact.

\section{Infections at Calving}

At calving, all herds had significantly more new cow and quarter infections in the untreated group (62 cows and 93 quarters) compared with the Teat Seal group (21 cows and 27 quarters $)(P<0.001$ for both cow and quarter) (Table 5). Of quarters infected at drying off there were 13 in the Teat Seal group and 21 infected by $S$. aureus, one $S$. uberis in both the Teat Seal and untreated groups, and one coliform in the untreated group. None of the quarters infected at drying off were observed to have clinical mastitis during the dry period or at calving. One cow with a $S$. aureus infection at drying off had a different quarter infected with $S$. aureus at calving. None of the infections present at drying off resolved spontaneously during the dry period.

\section{Pathogen Type in Quarters Infected at Calving}

The predominant pathogen causing new infections in both the untreated group and the Teat Seal group was S. uberis (Table 6). Nearly $50 \%$ of the infections in the untreated group and $33 \%$ in the Teat Seal group were due to $S$. uberis. There were herd differences in the second most common pathogen in both Teat Seal and untreated groups. S. aureus infections were most common in some herds and coliform infections in others.

Table 5. New infection status at calving for cow and quarter in all herds. Tests of association were carried out between treatment and clinical mastitis outcome for both cows and quarters using a chisquare test.

\begin{tabular}{lllllrrr}
\hline & \multicolumn{3}{c}{ Cow $^{\mathrm{a}}$} & & \multicolumn{3}{c}{ Quarter $^{\mathrm{b}}$} \\
\cline { 2 - 3 } \cline { 6 - 7 } & No & Yes & Total & & No & Yes & Total \\
\hline Teat Seal & 176 & 21 & 197 & & 757 & 27 & 784 \\
Untreated & 139 & 62 & 201 & & 706 & 93 & 799 \\
Total & 315 & 83 & 398 & & 1463 & 120 & 1583 \\
\hline
\end{tabular}

${ }^{\mathrm{a}} \chi^{2}=24.561 P<0.001$.

${ }^{\mathrm{b}} \chi^{2}=38.832 P<0.001$. 
Table 6. Prevalence for new infections at calving by pathogen type for cows and quarters (as a percentage of total cows or quarters) for all the herds.

\begin{tabular}{|c|c|c|c|c|}
\hline & \multicolumn{2}{|c|}{ Cow } & \multicolumn{2}{|c|}{ Quarter } \\
\hline & Teat Seal & Untreated & Teat Seal & Untreated \\
\hline & $\begin{array}{l}\text { No. }(\% \text { of } \\
\text { total cows) }\end{array}$ & $\begin{array}{l}\text { No. }(\% \text { of } \\
\text { total cows })\end{array}$ & $\begin{array}{l}\text { No. (\% of } \\
\text { total quarters) }\end{array}$ & $\begin{array}{c}\text { No. (\% of } \\
\text { total quarters) }\end{array}$ \\
\hline S. aureus & $7(3.5)$ & $20(9.9)$ & $8(1.0)$ & $27(3.3)$ \\
\hline S. uberis & $8(4.1)$ & 35 (18.9) & $9(1.1)$ & $44(5.4)$ \\
\hline Coliform & $5(2.5)$ & $7(3.4)$ & $7(0.9)$ & $10(1.2)$ \\
\hline S. dysgalacatiae & $1(0.05)$ & $3(1.5)$ & $1(0.1)$ & $6(0.7)$ \\
\hline $\begin{array}{l}\text { S. aureus + S. } \\
\text { dysgalactiae } \\
\text { A. pyogenes }+S .\end{array}$ & $0(0)$ & $1(0.5)$ & $0(0)$ & $1(0.1)$ \\
\hline $\begin{array}{l}\text { uberis } \\
\text { No sample or isolate }\end{array}$ & $0(0)$ & $3(1.5)$ & $0(0)$ & $3(0.3)$ \\
\hline $\begin{array}{l}\text { but treated as clinical } \\
\text { mastitis at calving }\end{array}$ & $1(0.5)$ & $1(0.5)$ & $2(0.1)$ & $2(0.1)$ \\
\hline Total & 21 (10.6) & $62(30.8)$ & $27(3.4)$ & $93(11.6)$ \\
\hline
\end{tabular}

Cows with mixed infections appear in more than one pathogen type row, accounting for the discrepancy in cow numbers.

\section{Clinical Mastitis in First 100 d of Lactation}

There was significantly more clinical mastitis in the untreated group than in the Teat Seal group during the first $100 \mathrm{~d}$ after calving in those quarters infected at calving $(P<0.001)$ (Table 7$)$. However, the percentages of quarters that were detected as having clinical mastitis signs were the same between treatment groups. The most common pathogen to cause clinical mastitis varied between herds. In the untreated group, $S$. uberis or $S$. aureus infections were most common. In the Teat Seal group coliform infections were the most common cause of clinical mastitis. One cow from the Teat Seal group was treated in all four quarters at calving with $S$. dysgalactiae isolated from one quarter, Corynebacterium spp. from one quarter and no pathogen isolated from the other two quarters.

\section{Prevalence of CNS and Corynebacterium spp. at Calving}

There were significantly more quarters infected with $S$. uberis at calving in quarters infected with Corynebacterium spp. at drying off than in uninfected quarters in both the Teat Seal and the untreated groups $(P<$ 0.001 in Teat Seal group and $P=0.003$ in untreated group) (Table 8). For quarters infected with CNS at drying off, there were only significantly more $S$. uberis infections at calving in the untreated group $(P=0.09$ in the Teat Seal group and $P=0.033$ in the untreated group). There were no significant differences in coliform infections between uninfected, CNS, or Corynebacte-

Table 7. Incidence of clinical mastitis in those quarters infected at calving (percentage of pathogen type present at calving).

\begin{tabular}{llc}
\hline $\begin{array}{l}\text { Clinical mastitis } \\
\text { pathogen }\end{array}$ & $\begin{array}{l}\text { Teat Seal group } \\
\text { (as \% of pathogen } \\
\text { type at calving) }\end{array}$ & $\begin{array}{l}\text { Untreated group } \\
\text { (as \% of pathogen } \\
\text { type atcalving) }\end{array}$ \\
\hline $\begin{array}{l}\text { S. aureus } \\
\text { S. uberis }\end{array}$ & $3(42)$ & $17(85)$ \\
$\begin{array}{l}\text { S. dysgalactiae } \\
\text { Coliform }\end{array}$ & $2(25)$ & $20(57)$ \\
$\begin{array}{l}\text { A. pyogenes }+ \text { S. uberis } \\
\text { No sample or isolate but } \\
\text { treated as clinical mastitis at } \\
\text { calving }\end{array}$ & $1(100)$ & $5(83)$ \\
$\begin{array}{l}\text { Corynebacterium spp. treated } \\
\text { as clinical at calving } \\
\text { Total clinical mastitis } \\
\text { infections }\end{array}$ & $0(050)$ & $5(50)$ \\
\hline
\end{tabular}

$$
{ }^{\mathrm{a}} \chi^{2}=25.015 P<0.001 \text {. }
$$


Table 8. Infection status at calving based upon infection status at drying off Test for an association between prevalence of $S$. uberis infection at calving and infection status at drying off only those significant indicated by odds ratio.

\begin{tabular}{|c|c|c|c|c|c|}
\hline Drying off status & $\begin{array}{l}\text { Number at } \\
\text { drying off }\end{array}$ & $\begin{array}{l}\text { Infected } \\
\text { with } \\
\text { S. uberis at } \\
\text { calving }\end{array}$ & $\begin{array}{l}\text { Infected } \\
\text { with coliform at } \\
\text { calving }\end{array}$ & $\begin{array}{l}\text { Infected } \\
\text { with } \\
\text { S. aureus at } \\
\text { calving }\end{array}$ & $\begin{array}{l}\text { Not infected } \\
\text { at calving }\end{array}$ \\
\hline \multicolumn{6}{|l|}{ Teat Seal quarters } \\
\hline Not infected & 478 & 0 & 5 & 5 & 453 \\
\hline $\mathrm{CNS}^{1}$ & 49 & 1 & 1 & 1 & 29 \\
\hline $\begin{array}{l}\text { Corynebacterium } \\
\text { spp. }\end{array}$ & 244 & $8 * *$ & 1 & 2 & 77 \\
\hline \multicolumn{6}{|l|}{ Untreated quarters } \\
\hline Not infected & 448 & 15 & 4 & 11 & 391 \\
\hline CNS & 64 & $6^{*}$ & 0 & 6 & 28 \\
\hline $\begin{array}{l}\text { Corynebacterium } \\
\text { spp. }\end{array}$ & 260 & $23^{* *}$ & 6 & 10 & 20 \\
\hline
\end{tabular}

rium spp. infected quarters for either treatment group ( $P=0.447, P=1$, for CNS and Corynebacterium spp., respectively in Teat Seal group and $P=0.669, P=0.13$ respectively in untreated group).

\section{DISCUSSION}

Logistic regression demonstrated an effect of treatment, along with the covariates infection status at drying off and cell count group, on the likelihood of a new intramammary infection at calving. Dry cow management was similar for both cell count groups for the relevant herds and for all herds either grazing on pasture or housed in straw yards, depending on the time of year.

Drying off status with respect to either Corynebacterium spp. or CNS was found to be a more significant covariate than cell count group. Although the prevalence of Corynebacterium spp.-infected quarters at drying off was not significantly different between cell count groups or treatment groups, significant differences were seen at the herd level and between cell count groups within herd. Herd remained as a forced covariate in the model although it was not significant once the covariate infection status at drying off was added. The amount of Corynebacterium spp. infection in a herd is considered an indicator of the thoroughness of teat disinfection (Bramley et al., 1976). Herd 4 had previously used an automatic exit race spray to apply teat disinfection, and had changed, within 18 months of starting the trial to manual teat spraying. Herds 1 and 5 were teat dipped, and herd 2 was teat sprayed thoroughly. Herds 3 and 6 were teat sprayed, and herd 3 had used only limited dry cow therapy for several years.
The level of Corynebacterium spp. infection in herds 3 , 4 , and 6 indicate that the teat disinfection was not as efficient as necessary, and this was combined with limited dry cow therapy in herd 3.

The higher cell count group included all cows that had had a clinical mastitis infection in the previous lactation. Higher cell counts possibly indicate previous exposure to infection. It is hardly surprising then that these cows were more likely to be infected at calving, taking into account that previous intramammary infection indicates increased susceptibility due to possible udder conformation or immunological differences (Stuart and Lancaster, 1949a; Stuart and Lancaster, 1949b).

The influence of parity on new intramammary infection was affected by pathogen type and dry cow therapy. An increase in infections due to coliforms, S. aureus, and $S$. uberis, with increasing parity was observed, but an increase in streptococcal infections was not seen in those herds using total dry cow therapy (Jayarao et al., 1999; Oliver and Mitchell, 1983; Oliver, 1988; Smith et al., 1985a; Smith et al., 1985b; Ward and Shultze, 1974). The prevalence of intramammary infections is generally likely to increase with parity, but it has not always been specified as to whether this is a cumulative effect of new and existing infections or the rate of new infections only, for that lactation (Oliver et al., 1956a; Oliver et al., 1956b; Smith et al., 1985a; Smith et al., 1985b). Increasing parity did not fit in the final model, contrasts with previous work on this subject. However, the majority of new infections in this work were due to $S$. uberis, and this model used the new intramammary infection rate. Previous models have not taken the infection status of quarters at drying off into account, which has 
quite clearly been shown to be an important covariate in this model.

The incidence of clinical mastitis during the dry period was $1.6 \%$ of quarters. This is lower than that reported by Australian and Dutch studies (Schukken et al., 1993; Hassan et al., 1999), but comparable to the incidence reported in a selective dry cow trial (Berry and Hillerton, 2002). Similarly, there was herd variation in the incidence of clinical mastitis, which is probably attributable to the herd management, especially that of the dry cows. A New Zealand study on Teat Seal reported that all clinical cases were detected by a periodic udder palpation that was carried out by one of the authors (Woolford et al., 1998), thus highlighting the importance of regular examination of the udder. There was a significant difference in the incidence of clinical mastitis during the dry period between the untreated and Teat Seal groups, with the most common pathogen being $S$. uberis. All clinical mastitis cases during the dry period in the New Zealand study were also $S$. uberis. The nonlactating udder is highly susceptible to certain infections, with the new infection rates being highest in the early dry period and approaching parturition. More than 50\% of these new infections will persist into the next lactation if not eradicated by appropriate treatment (Eberhart and Buckalew, 1972; Neave et al., 1950). S. uberis is considered to be the most common pathogen causing these infections in pastured and housed cattle in the UK (Cousins et al., 1979), and this is confirmed by this study.

There were significant differences in the rate of new infection at calving both at the cow and quarter level. The predominant pathogen causing the new infections in both groups was S. uberis, with nearly $50 \%$ of the cases in the untreated group due to this pathogen. This agrees with previous reports on the incidence of new infections and prevalence of $S$. uberis in the dry period and at calving (Eberhart and Buckalew, 1972; Neave et al., 1950; Oliver and Mitchell, 1983; Pearson, 1948; Smith et al., 1966; Woolford et al., 1998).

There were herd variations in the new infection rate and pathogen prevalence, but in all herds there was a reduction in the new infection rate in the Teat Seal group compared with the untreated group. There were nearly $80 \%$ fewer new S. uberis infections and $70 \%$ fewer new $S$. aureus infections at calving and $70 \%$ fewer new infections in total at calving in the Teat Seal group compared with the untreated group. This highlights the effectiveness of Teat Seal in preventing new infections during the dry period, particularly $S$. uberis and $S$. aureus infections, when compared with untreated cows. Similar results for $S$. uberis were demonstrated in New Zealand on a primarily outdoor grazing system (Woolford et al., 1998).
This trial was conducted over a winter housing and summer grazing period, in cows with a range of cell counts and infection status at calving, and demonstrates the efficacy of Teat Seal against a variety of environmental challenges. There were existing infections at drying off in both groups, and whilst none spontaneously resolved, infusing Teat Seal into quarters already infected did not result in any of these quarters showing clinical signs during the dry period or at calving. These existing infections may however account for some of the challenge to other cows for new $S$. aureus infections. It is not completely clear whether challenge comes from cross contamination at milking preceding drying off or from the infected quarters or other sources on the cows during the dry period (Browning et al., 1990; Eberhart and Buckalew, 1972). In this study, new $S$. aureus infections were observed when cows, even in herds where no quarters were known to be infected with $S$. aureus at drying off.

A significant reduction in clinical incidence in those quarters infected at calving in the first $100 \mathrm{~d}$ of lactation was observed between the Teat Seal and untreated groups. S. uberis was the most common pathogen causing clinical disease in the untreated group, with $S$. aureus the second most common. Coliforms were the most common cause of clinical mastitis in the Teat Seal group, but there were herd variations, with $S$. aureus being most common in some and coliforms in others. This is in agreement with the New Zealand data on clinical mastitis incidence (Woolford et al., 1998).

No statistically significant differences were found in the prevalence of Corynebacterium spp. or CNS between Teat Seal and untreated groups at drying off. There were herd variations due to management. There was no statistically significant difference in the prevalence of postcalving CNS between the two groups, but as before there were herd variations due to management differences. There was a lower prevalence of CNS postcalving in the Teat Seal group, but the numbers were low. As CNS are part of the normal skin flora and considered to be skin commensals, this is not unexpected (Harmon et al., 1984; Hogan et al., 1986). In addition, Teat Seal, being internal, is presumably unable to prevent teat duct colonization.

High cure rates for Corynebacterium spp. from 88 to $98 \%$ for dry cow therapy and self-cure rates ranging from 15 to $63.9 \%$ have been reported for dry cow therapy (Harmon et al., 1984; Hogan et al., 1994). Differences were seen in the apparent spontaneous cure rate of Corynebacterium spp. between the Teat Seal and untreated quarters, with the Teat Seal group having a higher spontaneous cure rate, but both were within ranges reported previously and not as high as rates achieved with dry cow therapy. 
The effect of existing infections due to Corynebacterium spp. and CNS on new and additional infections has been studied extensively in lactation (Bramley and Neave, 1975; Hogan et al., 1988; Honkanen-Buzalski et al., 1984; Lam et al., 1997; Matthews et al., 1991; Rainard and Poutrel, 1988). Limited data are available for the dry period, showing no protective effect of Corynebacterium spp. or CNS during the dry period against new intramammary infections (Woolford et al., 2001). This study also found no protective effect for Corynebacterium spp. or CNS for new S. uberis or coliform infections during the dry period or at calving. Indeed, there was an increased risk of Corynebacterium spp. or CNS infected quarters acquiring a new $S$. uberis infection in both the Teat Seal and the untreated group. This increased risk for acquiring a new $S$. uberis infection in Corynebacterium spp. infected quarters that are untreated at drying off is in agreement with previous work (Woolford et al., 2001; Berry and Hillerton, 2002). It has been previously speculated that the presence of Corynebacterium spp. or CNS might interfere with the formation of a natural teat seal (Williamson et al., 1995). Teats that received dry cow therapy have an earlier closure of the teat canal by a keratin seal. This study demonstrates that even in quarters that received an artificial teat sealant, there was still an increased risk of a $S$. uberis infection in those quarters with a Corynebacterium spp. or CNS infection compared with quarters uninfected at drying off. This suggests either that the Corynebacterium spp. or CNS interfere with Teat Seal efficacy, impair teat duct keratin plug formation or may aid in the colonization by $S$. uberis, e.g., by releasing nutrients essential for the establishment of infection (Kitt and Leigh, 1997).

Teat Seal was found in the foremilk of all treated cows after calving. Flecks of Teat Seal in the foremilk were reported on all herds in individual quarters of cows for up to $3 \mathrm{wk}$ after calving, but none reported this as a serious or widespread problem. Complete milking out of all quarters in newly calved cows is stressed, as incomplete milking can result in other problems, such as prolonged antibiotic residues (Hillerton et al., 1999). It is important that the Teat Seal is not confused with clinical signs of mastitis.

The importance of an aseptic technique was stressed in the New Zealand study (Woolford et al., 1998). In this trial, partial insertion of the Teat Seal was practiced, in contrast to full insertion in the New Zealand study. Whilst an aseptic technique was practiced in this study, the method was not beyond that recommended by pharmaceutical manufacturers for insertion of intramammary tubes at drying off. This technique could easily be followed in a normal milking routine.

\section{CONCLUSIONS}

Compared with no treatment, application of Teat Seal (now Orbeseal) to all quarters at drying off resulted in significantly fewer new intramammary infections at calving, less clinical mastitis during the dry period, and fewer cases of clinical mastitis in the $100 \mathrm{~d}$ of the subsequent lactation. Teat Seal provides a viable alternative to dry cow therapy for the organic dairy industry and those seeking to reduce the prophylactic use of antibiotics. A protective effect of Corynebacterium spp. or CNS against infection by other pathogens was not demonstrated. On the contrary, there was an increased risk of a new infection by $S$. uberis in these quarters.

\section{ACKNOWLEDGMENTS}

This work was supported by Biotechnology and Biological Sciences Research Council and Cross Vetpharm Group. We are grateful to all the farms and herdspersons for their cooperation with this work, and to Kirsty Kliem and Vicky Cocks for their help.

\section{REFERENCES}

Berry, E. A., and J. E. Hillerton. 2002. The effect of selective dry cow treatment on new intramammary infections J. Dairy Sci. 85:112.

Bramley, A. J., R. G. Kingwell, T. K. Griffin, and D. L. Simkin. 1976. Prevalence of Cornyebacterium bovis in bovine milk samples. Vet. Rec. 99:275.

Bramley, A. J., and F. K. Neave. 1975. Studies on the control of coliform mastitis in dairy cows. Br. Vet. J. 131:160.

Browning, J. W., G. A. Mein, M. Barton, T. J. Nicholls, and P. Brightling. 1990. Effects of antibiotic therapy at drying off on mastitis in the dry period and early lactation. Aus. Vet. J. 67:440.

Comalli, M. P., R. J. Eberhart, L. C. Griel Jr., and H. Rothenbacher. 1984. Changes in the microscopic anatomy of the bovine teat canal during mammary involution. Am. J. Vet. Res. 45:2236.

Cousins, C. L., T. M. Higgs, E. R. Jackson, F. K. Neave, and F. H. Dodd. 1979. Susceptibility of the bovine udder to bacterial infection in the dry period. J. Dairy Res. 47:11.

Day, A. M. 1990. Dry period mastitis. Dairy Cattle Newsletter, N. Z. Vet. Assoc. 7:7.

Eberhart, R. J., and J. M. Buckalew. 1972. Evaluation of a hygiene and dry period therapy program for mastitis control. J. Dairy Sci. 55:1683.

Harmon, R. J., W. L. Crist, R. W. Hemken, and B. E. Langlois. 1984. Prevalence of minor udder pathogens after intramammary dry treatment. J. Dairy Sci. 69:843.

Hassan, Z., R. C. Daniel, D. O’Boyle, and A. J. Frost. 1999. Effects of dry cow intramammary therapy on quarter infections in the dry period. Vet. Rec. 145:635.

Hemling, T. M., K. E. Henderson, K. E. Leslie, G. H. Lim, and L. L. Timms. 2000. Experimental models for the evaluation of the adherence of dry cow teat sealants, Page 248 In: Proceedings of 39th Annual Meeting, National Mastitis Council, Atlanta, Georgia.

Hillerton, J. E., B. I. Halley, P. Neaves, and M. D. Rose. 1999. Detection of antimicrobial substances in individual cow and quarter milk samples using Delvotest microbial inhibitor tests. J. Dairy Sci. 82:704.

Hogan, J. S., K. L. Smith, D. A. Todhunter, and P. S. Schoenberger. 1988. Rate of environmental mastitis in quarters infected with Corynebacterium bovis and Staphylococcus species. J. Dairy Sci. 71:2520. 
Hogan, J. S., K. L. Smith, D. A. Todhunter, P. S. Schoenberger, R. P. Dinsmore, M. B. Canttell, and C. S. Gabel. 1994. Efficacy of dry cow therapy and a Propionibacterium acnes product in herds with low somatic cell count. J. Dairy Sci. 77:3331.

Hogan, J. S., D. G. White, and J. W. Pankey. 1986. Effects of teat dipping on intramammary infections by staphylococci other than Staphylococcus aureus. J. Dairy Sci. 70:873.

Honkanen-Buzalski, T., T. K. Griffin, and F. H. Dodd. 1984. Observations on Corynebacterium bovis infection of the bovine mammary gland. I. Natural infection. J. Dairy Res. 51:371.

IDF. 1981. Laboratory methods for use in mastitis work. Bulletin No. 132. International Dairy Federation, Brussels.

Jayarao, B. M., B. E. Gillespie, M. J. Lewis, H. H. Dowlen, and S. P. Oliver. 1999. Epidemiology of Streptococcus uberis intramammary infections in a dairy herd. J. Vet. Med. B. 46:433.

Kitt, A. J., and J. A. Leigh. 1997. The auxotrophic nature of Streptococcus uberis. The acquisition of essential acids from plasmin derived casein peptides. Adv. Exp. Med. Biol. 418:647.

Lam, T. J., Y. H. Schukken, J. H. van Vliet, F. J. Grommers, M. J. Tielen, and A. Brand. 1997. Effect of natural infection with minor pathogens on susceptibility to natural infection with major pathogens in the bovine mammary gland. Am. J. Vet. Res. 58:17.

Matthews, K. R., R. J. Harmon, and B. E. Langlois. 1991. Effect of naturally occurring coagulase-negative staphylococci infections on new infections by mastitis pathogens in the bovine. J. Dairy Sci. 74:1855.

Meaney, W. J. 1977. Effect of dry period teat sealant on bovine udder infections. Irish J. Ag. Res. 16:293.

Neave, F. K., F. H. Dodd, and E. Henriques. 1950. Udder infections in the dry period. J. Dairy Res. 17:37.

Oliver, J., F. H. Dodd, and F. K. Neave. 1956a. Infection and mastitis in a dairy herd. J. Dairy Res. 23:169.

Oliver, J., F. H. Dodd, F. K. Neave, and G. L. Bailey. 1956b. Variations in the incidence of udder infection and mastitis with stage in lactation, age and season of year. J. Dairy Res. 23:181.

Oliver, S. P. 1988. Influence of parity on intramammary infections by environmental mastitis pathogens during the dry period. AgriPractice. 9:7.

Oliver, S. P., and B. A. Mitchell. 1983. Susceptibility of bovine mammary gland to infections during the dry period. J. Dairy Sci. $66: 1162$.
Pearson, J. K. L. 1948. Bovine mastitis and Penicillin. Proc. Appl. Microbiol. 27.

Rainard, P., and B. Poutrel. 1988. Effect of naturally occurring intramammary infections by minor pathogens on new infections by major pathogens in cattle. Am. J. Vet. Res. 49:327.

Ryan, M. P., J. Flynn, C. Hill, R. P. Ross, and W. J. Meaney. 1999. The natural food grade inhibitor, lacticin 3147, reduced the incidence of mastitis after experimental challenge with Streptococcus dysgalactiae in nonlactating dairy cows. J. Dairy Sci. 82:2625.

Schukken, Y. H., J. Vanvliet, D. Vandegeer, and J. Grommers. 1993 A randomized blind trial on dry cow antibiotic infusion on a low somatic cell count herd. J. Dairy Sci. 76:2925.

Smith, A., F. K. Neave, and F. H. Dodd. 1966. Methods of reducing the incidence of udder infection in dry cows. Vet. Rec. 79:233.

Smith, K. L., D. A. Todhunter, and P. S. Schoenberger. 1985a. Environmental pathogens and intramammary infection during the dry period. J. Dairy Sci. 68:402.

Smith, K. L., D. A. Todhunter, and P. S. Schoenberger. 1985b. Environmental mastitis: cause, prevalence, prevention. J. Dairy Sci. 68:1531.

Stuart, P., and J. E. Lancaster. 1949a. Experiments on the transmission of Streptococcus agalactiae infections by milking with infected hands. J. Comp. Path. 59:19.

Stuart, P., and J. E. Lancaster. 1949b. Some factors which may be concerned in the susceptibility of the bovine udder to Streptococcus agalactiae infection. J. Comp. Path. 59:31.

Timms, L. L., A. Steffans, S. Piggott, and L. Allen. 1997. Evaluation of a novel persistent barrier teat dip for preventing mastitis during the dry period. Page 206. Proceedings of 36th National Mastitis Council.

Ward, G. E., and L. H. Shultze. 1974. Incidence and control of mastitis during the dry period. J. Dairy Sci. 57:1341.

Williamson, J. H., M. W. Woolford, and A. M. Day. 1995. The prophylactic effect of a dry cow antibiotic against Streptococcus uberis. N. Z. Vet. J. 43:228.

Woolford, M. W., J. H. Williamson, A. M. Day, and P. J. A. Copeman. 1998. The prophylactic effect of a teat sealer on bovine mastitis during the dry period and the following lactation. N. Z. Vet. J. 46:12.

Woolford, M. W., J. H. Williamson, A. M. Day, S. J. Lacy-Hulbert, and H. V. Henderson. 2001. Effect of localized antibiotic infusions applied to the teat canal and teat sinus at drying off on mastitis in the dry period and at calving. J. Dairy Res. 68:551. 